\title{
Assessing the influence of source distance and hydroecoregion on the invertebrate assemblage similarity in central Italy streams
}

\author{
L. Traversetti ${ }^{(1), \star}$, M. Scalici ${ }^{(1)}$ \\ Received November 22, 2013 \\ Revised March 7, 2014 \\ Accepted March 7, 2014
}

\section{ABSTRACT}

Key-words: Increasing the river habitat safeguard level is one of the main actions proHER, posed by the European Water Framework Directive in the field of biomonmacroinvertebrate, itoring. To do so, watercourses within the same hydroecoregions (that is, monitoring, homogeneous areas based on climate, geology and topography) ought source distance, to be compared. In addition, the source distance was thought to play an watercourse important role in comparing rivers and then planning monitoring activities. The purpose of this study was to evaluate if both hydroecoregion and source distance affect the response (in terms of taxa assemblage) of one of the most used group in the river monitoring activities: the benthic macroinvertebrate. Here we proposed the comparative influence of hydroecoregion and source distance on the invertebrate assemblage in Mediterranean rivers of central Italy. Our statistical outputs highlighted how macroinvertebrate differed for both hydroecoregions and source distance ranks. In particular, no differences were found among sites of different (1) source distance ranks and (2) hydroecoregion (that is, when this two descriptors were analyzed separately), while the highest difference in the macroinvertebrate assemblage was observed between the same source distance ranks of different hydroecoregions. Our results showed how the use of both hydroecoregion and source distance should be considered for planning monitoring activities to properly manage rivers and water resources.

\section{RÉSUMÉ}

Évaluation de l'influence de la distance à la source et de l'hydroécorégion sur la similitude d'assemblages d'invertébrés dans les cours d'eau d'Italie centrale
Mots-clés :
L'augmentation du niveau de protection de l'habitat des rivières est l'une des prin- HER, macro- invertébrés, surveillance, distance de la source, cours d'eau cipales mesures proposées par la directive-cadre sur l'eau dans le domaine de
la biosurveillance. Pour ce faire, les cours d'eau dans les mêmes hydroécoré-
gions (c'est-à-dire, des zones homogènes en fonction du climat, de la géologie et
de la topographie) doivent être comparés. De plus, la distance à la source a été
supposée jouer un rôle important dans les comparaisons de rivières et la planifi-
cation des activités de surveillance. Le but de cette étude était d'évaluer si à la
fois les hydroécorégions et la distance à la source affectent la réponse (en termes
d'assemblage de taxons) de l'un des groupes les plus utilisés dans les activités 


\begin{abstract}
de surveillance des rivières : les macro-invertébrés benthiques. Ici, nous avons envisagé l'influence partagée des hydroécorégions et de la distance à la source sur l'assemblage d'invertébrés dans les rivières méditerranéennes de l'Italie centrale. Nos résultats statistiques ont mis en évidence la façon dont les macroinvertébrés diffèrent pour à la fois les hydroécorégions et les classes de distance à la source. En particulier, aucune différence n'a été constatée entre les sites de rangs différents (1) de distance à la source, et (2) les hydroécorégions (c'est-à-dire, lorsque ces deux descripteurs ont été analysés séparément), tandis que la plus grande différence dans l'assemblage des macro-invertébrés a été observée entre les rangs de même distance à la source de différentes hydroécorégions. Nos résultats ont montré comment l'utilisation simultanée des hydroécorégions et de la distance à la source doit être considérée pour la planification des activités de surveillance pour gérer correctement les rivières et les ressources en eau.
\end{abstract}

\title{
INTRODUCTION
}

Inland waters and their natural resources are constituted by ecologically and economically important habitats. To date, these ecosystems are unfortunately considered among the most threatened (Schlosser, 1991; Frissell and Bayles, 1996; Feio et al., 2010). Many treats make vulnerable a large proportion of aquatic organisms particularly in systems harboring a highly endemic fauna, such as Mediterranean freshwaters (Ricciardi and Rasmussen, 1999; Smith and Darwall, 2006; Reyjol et al., 2007). Then preserving freshwater habitats is fundamental to achieve a sustainable exploitation of their resources.

The increasing need to safeguard the running water habitats led to propose a series of actions for the protection and preservation of water and aquatic resources. For this reason, the UE countries proposed the Water Framework Directive (WFD, 2000/60/EC) to reach a suitable tool of water managing before 2015 . One of the WFD requirement is to plan managing activities for all the river basin districts based on water quality maps obtained by several biological multiparametric approaches. To do this, Wasson et al. (2002) proposed a new approach based on the comparisons among river courses included within the same hydroecoregions (HER), the latter being analogues to the terrestrial ecoregions (see Illies, 1978). HERs were defined as homogeneous areas characterized by similar climate, geology and topography (Wasson et al., 2002). Three different HERs have been defined in central Italy: HER13 (H13, Central Apennines), HER14 (H14, Rome and Tuscia) and HER15 (H15, Lower Latium) (Figure 1). H13 is a mainly mountainous hydroecoregion while $\mathrm{H} 14$ and $\mathrm{H} 15$ have lower altitude reliefs (mainly hills for $\mathrm{H} 14$ and plains formed by rivers matter deposition for H15) (Traversetti et al., 2013).

A second useful criterion for classifying watercourses consist in dividing rivers into diverse ranks depending on the source distance (SD). In particular, Buffagni et al. (2006) proposed 5 SD ranks: SD1 (1-5 km from the source), SD2 (6-25 km), SD3 (26-75 km), SD4 (76-150 km) and SD5 (>150 km).

HERs and SD ranks are identified as a new tool of running waters' division to contribute to propose appropriate monitoring or environmental assessment programs taking natural environmental heterogeneity of watercourses into account. Different studies focussed on the effect of SD on structuring macroinvertebrate assemblages (e.g., Turak et al., 1999; Aguiar et al., 2002; Tomanova et al. , 2007) while only few studies focussed on HER in Alpine (Urbanič, 2008; Tavzes and Urbanič, 2009) and central Appennine hydroecoregions (Pace et al., 2011, 2012).

To contribute to the knowledge of the macroinvertebrate assemblage pattern in different Mediterranean streams, the purpose of this study was to evaluate if both hydroecoregion and source distance (and their eventual synergy) affect occurrence and abundance of the benthic macroinvertebrate. 


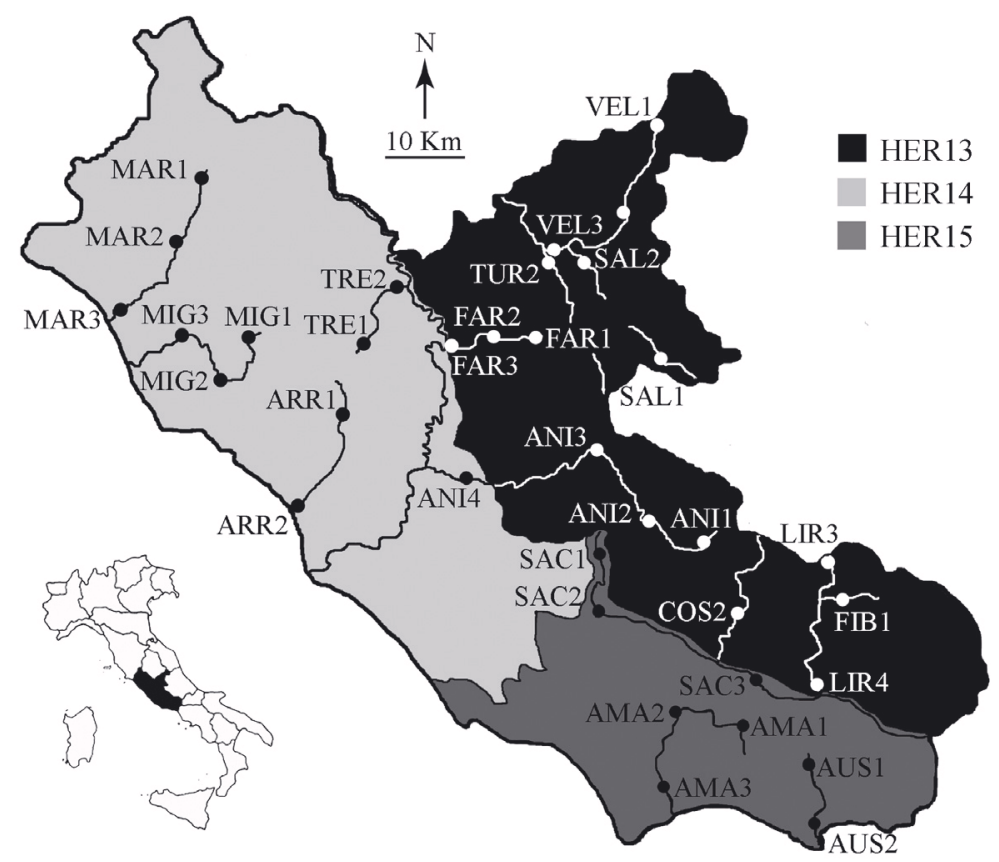

Figure 1

Location of the sampling sites within the study area. Acronyms: $A M A=$ River Amaseno; $A N I=$ River Aniene; $A R R=$ River Arrone; AUS = River Ausente; COS = River Cosa; FAR = River Farfa; FIB = River Fibreno; $L I R=$ River Liri; MAR = River Marta; MIG = River Mignone; SAC = River Sacco; SAL = River Salto; TRE = River Treja; TUR = River Turano; VEL = River Velino. Subsequent acronym number define the source distance rank of each sampling site $(1=S D 1,2=S D 2,3=S D 3,4=S D 4)$.

\section{Table I}

Number of sampling sites per HER and per SD.

\begin{tabular}{|l|c|c|c|}
\hline $\begin{array}{l}\text { Hydroecoregion } \\
\text { (HER) }\end{array}$ & $\begin{array}{c}\text { Source distance } \\
(\text { SD, } \mathbf{k m})\end{array}$ & $\begin{array}{c}\text { Source distance } \\
\text { ID }\end{array}$ & No. site \\
\hline \multirow{4}{*}{ H13 } & $1-5$ & SD1 & 5 \\
\cline { 2 - 4 } & $6-25$ & SD2 & 6 \\
\cline { 2 - 4 } & $26-75$ & SD3 & 4 \\
\cline { 2 - 4 } & $76-150$ & SD4 & 1 \\
\hline \multirow{4}{*}{ H14 } & $1-5$ & SD1 & 4 \\
\cline { 2 - 4 } & $6-25$ & SD2 & 4 \\
\hline \multirow{4}{*}{$\mathbf{H} 15$} & $26-75$ & SD3 & 2 \\
\cline { 2 - 4 } & $76-150$ & SD4 & 1 \\
\cline { 2 - 4 } & $1-5$ & SD1 & 3 \\
\cline { 2 - 4 } & $6-25$ & SD2 & 3 \\
\cline { 2 - 4 } & $26-75$ & SD3 & 2 \\
\hline
\end{tabular}

\section{MATERIAL AND METHODS}

\section{>PROTOCOL DESIGN AND MACROINVERTEBRATE COLLECTION}

We investigated 15 streams (35 sampling sites, divided according to HER and SD rank criterions) in July 2012 located in Latium Region, central Italy (Figure 1, Supplementary material I', Table I). In each site, the sample collection was carried out from downstream to upstream by kicking the riverbed for $60 \mathrm{~s}$ and collecting specimens with a standard net $(25 \times 25 \mathrm{~mm}$ frame, mesh $500 \mu \mathrm{m})$. More in detail, the sampling area was previously defined with the use of a wooden square built in order to define a precise sampling area. This square was putted

\footnotetext{
1 Available at: http://www.kmae-journal.org/.
} 
in front of the net and anly this area was kicked. This shrewdness was followed to calculate abundances $\times$ area and to define total abundances (quantitative approach). We collected a total of 10 samples from all the investigated site. In particular, we sampled proportionally all microhabitats with a minimum coverage of $10 \%$ of the river bed, surveying every $10 \%$ of the river bed surface (e.g., microhabitats with a coverage of $60 \%$ was sampled 6 times) (Hering et al., 2004, 2006; Pace et al., 2011). Macroinvertebrate were grossly sorted in field, preserved in $85 \%$ ethanol and than identified in laboratory to genus level (only Coleoptera, Diptera, Hydracarinae and Oligochaeta were identified at family or sub-family) based on the literature and on Tachet et al. (2000) taxonomic guide. Prior to analysis, taxonomic abundances were converted to individuals $\cdot \mathrm{m}^{-2}$. Sampling sites were first pooled in two different ways as follows: (1) according to the hydroecoregion criterion (beHER); (2) according to the source distance rank criterion (beSD). Analyses were run in parallel for these two groups. Finally, we performed a third comparison using sampling sites of the same source distance rank among different hydroecoregions (wiSD). The unique site within the SD5 was disregarded since no comparisons may be performed.

\section{> PHYSICO-CHEMICAL COMPARISON OF SITES}

Before sampling, 11 physico-chemical environmental variables were surveyed: conductivity $\left(C\right.$, $\left.\mu \mathrm{s} \cdot \mathrm{cm}^{-1}\right)$, dissolved oxygen $\left(\mathrm{O}_{2}, \mathrm{mg} \cdot \mathrm{L}^{-1}\right), \mathrm{O}_{2}$ saturation $(\mathrm{S}, \%)$, $\mathrm{pH}$, temperature $\left(T,{ }^{\circ} \mathrm{C}\right)$ in situ by an immersion probe (WTW Multi 340i/SET) while ammonium $\left(\mathrm{NH}_{4}^{+}\right.$, mg. $\mathrm{L}^{-1}$ ), chemical oxygen demand $\left(\mathrm{COD}, \mathrm{mg} \cdot \mathrm{L}^{-1}\right)$, nitrates $\left(\mathrm{NO}_{3}^{-}, \mathrm{mg} \cdot \mathrm{L}^{-1}\right)$ and orthophosphate $\left(P, \mathrm{mg} \cdot \mathrm{L}^{-1}\right)$ by a field spectrophotometer (WTW Photometer MPM). Water velocity $\left(V, \mathrm{~cm} \cdot \mathrm{s}^{-1}\right)$ and altitude (A, $m$ a.s.I.) were measured by the flowmeter General Oceanics 2030 series and the GPS Garmin Dakota 10, respectively. Physico-chemical environmental variables were called 'physico-chemical' hereafter.

All the environmental variables were log-transformed, since most of them did not follow a Gaussian distribution (after the normality assessment by the Kolmogorov-Smirnov test). Then, these variables were tested for collinearity, and those showing significant positive and negative correlation were not used in the analyses. The following 6 variables were considered in the analyses: ammonium, conductivity, nitrates, orthophosphate, $\mathrm{pH}$, and temperature.

To obtained a descriptive habitat characterization of all sampling sites, we assessed physicochemical differences among sampling sites by a principal component analysis (PCA) using the environmental variables. To show the overlapping between HER sites, 95\% probability ellipses were shown by grouping beHER separately. Finally, a multiple Spearman's correlation between the first 2 PCs vs. each one of the physico-chemical was performed to highlight driving forces explaining the site distribution in the scatter plot.

\section{$>$ INDICES AND METRICS}

To provide a preliminary biological description of the investigated sites, 4 macroinvertebrate metrics were calculated: taxonomic richness (R), total abundance (a), evenness (e), and Shannon-Wiener $(\mathrm{H})$ (Supplementary material II).

Additionally, two indices were calculated to give information on the anthropic impact on the river: (1) the River Functionality Index (IFF, from the Italian Indice di Funzionalità Fluviale; Siligardi et al., 2007), and (2) the Land Use Index (LUI, Ometo et al., 2000). The IFF was derived from the Riparian Channel and Environment Inventory (RCEI) published by Petersen (1992) and adapted for the Italian context by Siligardi et al. (2007). The output score attributes a score corresponding to a quality class (ranging from I for very good quality to $\mathrm{V}$ for very bad one) to each site (Supplementary material II). The land use index (LUI) was calculated for a $1 \mathrm{~km}$ radius around each site according to Ometo et al. (2000) to evaluate anthropic impact. A value ranging from 0 (areas with very low or no impact) to 5 (high impact) was assigned 
to each site (Supplementary material II). Both the indices and the metrics used were called 'metrics' hereafter.

First of all, metrics were tested for normality using Kolmogorov-Smirnov test. Since they followed a normal distribution, metrics were compared using paired t-tests to evaluate the influence of HER and SD on similarities. Precisely, t-tests were performed for beHER and beSD as well as for wiSD. To reduce Type I error or the false rejection of the null hypothesis (i.e. there is no difference between the methods), the sequential Bonferroni procedure (Holm, 1979) was calculated (Feeley et al., 2012).

Finally, to compare physico-chemicals and metrics, a multiple Spearman's correlation was performed between the first 2 PCs from physico-chemicals PCA vs. each one of the metric.

\section{> BIOLOGICAL COMPARISON OF SITES}

The one-way analysis of similarity (ANOSIM) was used to test whether the macroinvertebrate assemblages were significantly different for beHER and wiSD. This is a multivariate permutation procedure widely used with macroinvertebrate assemblages (e.g., Álvarez-Cabria et al., 2011; Almeida et al., 2013) to verify similarity in their composition between sampling sites. This test returns an $R$ value estimating the strength of sampling sites separation varying from 1 (higher similarity) to 0 (no similarity) (Clarke, 1993). This test was performed with a number of 1000 permutations.

Then, similarity percentage analysis (SIMPER) were employed to determine which taxa contributed most to any dissimilarities for beHER. Also for this analysis, the mean abundances calculated for ANOSIM were used. SIMPER uses a Bray-Curtis similarity matrix to compute the overall average dissimilarity between all pairs of sampling site groups (Clarke, 1993). This analysis returns a mean abundance value for all taxa belonging to each group. The mean abundance of taxa that contributing up to $80 \%$ to the dissimilarity between groups was evaluated.

Finally, to evaluate differences between sampling sites, we used a non-metric multidimensional scaling (NMDS, Kruskal, 1962a) analysis on taxa abundances, using a Bray-Curtis distance measure. NMDS provides a multiple dimensional perspective in ordination space to visualize variation among sampling sites using whole community data. Briefly, this is an analysis of the distance upon dissimilarity performed on a monotone regression. The residual variance (suitably normalized) is called the 2D stress (Kruskal, 1964a). It return a 2D stress value that estimate of how well the analysis describes patterns from the data set. In particular, the stress is a description of the strict match between the data and the configuration (Kruskal, 1964b). This analysis was performed using a double level approach. First of all, two analyses on beHER and beSD were performed, separately. Successively, differences for wiSD were analized to eliminate the source distance effect on macroinvertebrate and to better evaluate the influence of HER solely. Due to the fact that only two sites per SD4 were sampled, this second approach was not followed for these ones since it would not make sense.

All statistical analyses were performed with Statistica 7 Stat. Soft. and PAST package ver. $1.94 b$.

\section{RESULTS}

\section{> PHYSICO-CHEMICAL COMPARISON OF SITES}

The physico-chemical features were used to produce the diagram in Figure $2 \mathrm{a}$ (by using the first two PCs explaining $88.54 \%$ of the total variance) where it was not possible to clearly distinguish beHER. Three selected environmental variables were significantly correlated with PC1 (nitrates, orthophosphate, and temperature) while only pH with PC2.

The three scatter plots obtained by using the within each SD sites also showed a partial sites overlap as in Figures 2b, 2c, 2d. 

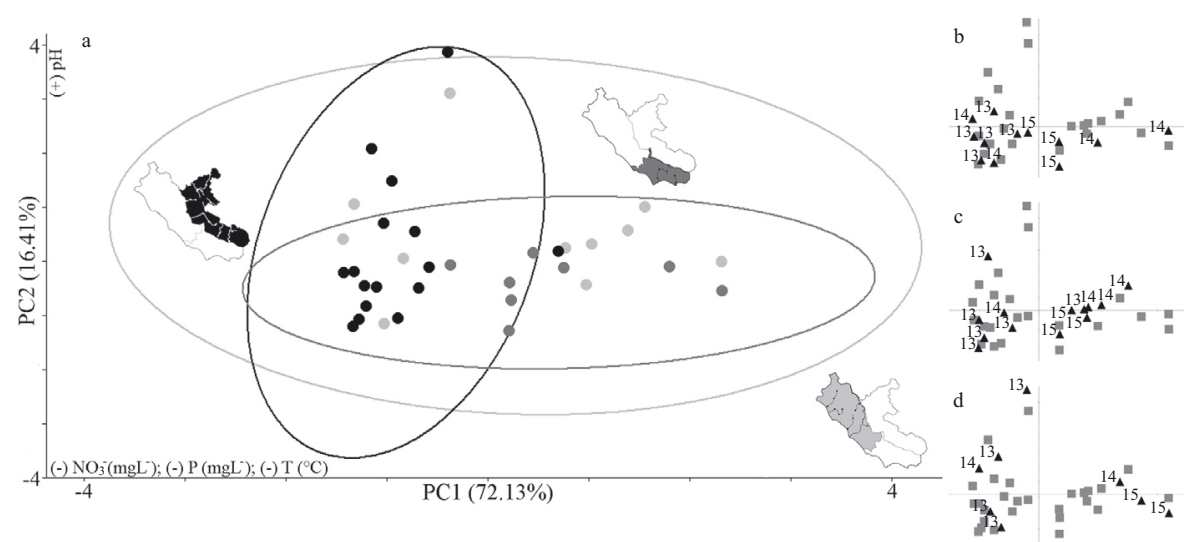

Figure 2

Scatter plots of the principal component analysis (performed on the physicochemical variables) obtained using the first two PC scores (a). + and - highlight physicochemicals positively and negatively correlated with PCs, black point = hydroecoregion 13; dark gray points = hydroecoregion 14; light gray points = hydroegoregion 15. Scatter plots indicating sites within each SD were showed in the detailed plots on the right. Black triangles correspond to sites within SD1 (b), SD2 (c) and SD3 (d). Acronyms: $\mathrm{NO}_{3}^{-}=$ nitrates; $P$ = orthophosphate; $T$ = temperature.

\section{Table II}

Comparison between macroinvertebrate assemblages between HER (beHER), between SD (beSD) and between HER within each SD (wiSD) by using paired t-tests. All $t$ values are reported and significant correlations are shown with ${ }^{*}\left({ }^{*}=p<0.05 ;{ }^{*}=p<0.01\right)$. $a=$ total abundance; $e=$ evenness; $H=$ Shannon-Wiener index; IFF = River Functionality Index value; $L U I=$ Land Use Index; $R=$ taxonomic richness.

\begin{tabular}{|c|c|c|c|c|c|c|c|c|}
\hline & Sites & IFF & LUI & a & e & $H$ & $R$ \\
\hline \multirow{3}{*}{\multicolumn{2}{|c|}{ beHER }} & 13 vs. 14 & 2.04 & 0.72 & $3.55^{\star \star}$ & 1.82 & $2.01^{\star}$ & $2.92^{\star \star}$ \\
\hline & & 13 vs. 15 & 0.15 & 1.13 & $3.41^{\star \star}$ & 1.59 & 1.46 & 2.35 \\
\hline & & 14 vs. 15 & $2.09^{\star}$ & 1.92 & 1.14 & 0.20 & 0.25 & 0.25 \\
\hline \multirow{6}{*}{\multicolumn{2}{|c|}{ beSD }} & 1 vs. 2 & $2.23^{*}$ & 0.87 & 0.50 & 1.22 & 0.11 & 1.07 \\
\hline & & 1 vs. 3 & 1.62 & 0.38 & 1.99 & 1.50 & 0.44 & 1.26 \\
\hline & & 1 vs. 4 & $2.97^{*}$ & $4.65^{\star \star}$ & 1.57 & 1.96 & 0.87 & $2.54^{*}$ \\
\hline & & 2 vs. 3 & 0.48 & 0.37 & 1.32 & 0.54 & 0.39 & 0.40 \\
\hline & & 2 vs. 4 & 1.21 & $3.03^{*}$ & 1.17 & 1.63 & 1.21 & 1.59 \\
\hline & & 3 vs. 4 & 1.72 & $3.42^{\star \star}$ & 1.25 & 1.39 & 0.46 & 0.98 \\
\hline \multirow{9}{*}{ wiSD } & \multirow{3}{*}{ SD1 } & 13 vs. 14 & 1.87 & 0.73 & $2.49^{*}$ & 1.11 & 0.20 & 0.80 \\
\hline & & 13 vs. 15 & 1.78 & 0.84 & 1.61 & 1.41 & 1.15 & 0.19 \\
\hline & & 14 vs. 15 & 0.25 & 0.08 & 1.50 & 0.02 & 0.58 & 0.86 \\
\hline & \multirow{3}{*}{ SD2 } & 13 vs. 14 & 1.16 & 0.07 & $3.28^{*}$ & 1.99 & 2.01 & $2.68^{*}$ \\
\hline & & 13 vs. 15 & 1.29 & 1.66 & 0.97 & 0.08 & 0.15 & 0.04 \\
\hline & & 14 vs. 15 & 0.19 & 1.57 & 2.08 & 1.32 & 1.32 & 2.46 \\
\hline & \multirow{3}{*}{ SD3 } & 13 vs. 14 & 0.95 & 0.38 & 1.68 & 0.11 & $3.57^{*}$ & 1.96 \\
\hline & & 13 vs. 15 & 2.56 & 2.41 & 0.91 & 1.48 & 2.32 & 0.89 \\
\hline & & 14 vs. 15 & 0.46 & 1.10 & 1.91 & 0.93 & 1.52 & 2.46 \\
\hline
\end{tabular}

\section{$>$ INDICES AND METRICS}

Differences in metrics were relevant between sampling sites, in particular considering the upstream/downstream variability usually expected between sites distributed along the same river. The t-test values obtained for beHER and beSD showed 11/63 significant differences while lower number of significant differences (4/63) was obtained for wiSD (Table II). All indices and metrics tested were found not to be significantly different using the sequential Bonferroni procedure for all comparisons. Almost all metrics were significantly correlated with PC1 excepted for evenness while no significant correlations were obtained with PC2. 


\section{Table III}

Comparison of sampling site macroinvertebrate assemblages using ind $\mathrm{m}^{2}$ by analysis of similarity. Significant similarity values are shown with ${ }^{*}\left({ }^{*}=p<0.05 ;{ }^{* *}=p<0.01\right)$.

\begin{tabular}{|l|c|c|}
\cline { 2 - 3 } \multicolumn{1}{c|}{} & Sites & R \\
\hline \multirow{3}{*}{ Total } & H13 vs. H14 & $0.46^{* *}$ \\
\cline { 2 - 3 } & H13 vs. H15 & 0.13 \\
\cline { 2 - 3 } & H14 vs. H15 & $0.37^{* *}$ \\
\hline \multirow{3}{*}{ SD1 } & H13 vs. H14 & $0.48^{* *}$ \\
\cline { 2 - 3 } & H13 vs. H15 & 0.24 \\
\cline { 2 - 3 } & H14 vs. H15 & 0.01 \\
\hline \multirow{3}{*}{ SD2 } & H13 vs. H14 & $0.79^{* *}$ \\
\cline { 2 - 3 } & H13 vs. H15 & 0.26 \\
\cline { 2 - 3 } & H14 vs. H15 & $0.80^{*}$ \\
\hline \multirow{3}{*}{ SD3 } & H13 vs. H14 & 0.71 \\
\cline { 2 - 3 } & H13 vs. H15 & 0.79 \\
\cline { 2 - 3 } & H14 vs. H15 & 0.50 \\
\hline
\end{tabular}

\section{>BIOLOGICAL COMPARISON OF SITES}

Comparisons of similarity (ANOSIM) calculated for beHER showed $2 / 3$ cases of significant similarity while this value decreased to $3 / 9$ compared with wiSD (Table III). The highest assemblage composition similarity was founded between $\mathrm{H} 13$ and $\mathrm{H} 14$ in both cases while a total dissimilarity was obtained between $\mathrm{H} 13$ and $\mathrm{H} 15$ (no significant values).

BeHER overall average dissimilarities, calculated using SIMPER, were $88.60 \%$ (between $\mathrm{H} 13 / \mathrm{H} 14), 82.01 \%(\mathrm{H} 13 / \mathrm{H} 15)$ and $85.97 \%(\mathrm{H} 14 / \mathrm{H} 15)$. SIMPER analysis was performed to highlight taxon or group of taxa responsible for the dissimilarity highlighted by ANOSIM analysis. Complete results are shown in Table IV. However, taxa contributing the most to assemblage changes in similarity varied considerably for beHER (Table IV).

The NMDS scatter plot for beSD and beHER (Figure 3) showed that sites almost completely overlap. These two scatter plots were performed with a low 2D stress value $(0.23)$. On the contrary, scatter plots obtained for wiSD showed a greater distinction between sites (Figure 4). Stress values were low, ranging from 0.13 to 0.22 .

\section{DISCUSSION}

In view of the specific European requirements (see Introduction) on the need to improve the environmental health monitoring activities, no studies evaluate differences in response of macroinvertebrate to diverse hydroecoregions and source distance ranks. If on one hand anthropogenic degradation of riverine systems stimulated a multi-assemblage habitat assessment, on the other hand European guidelines remain poorly applied overall in Mediterranean rivers in central Italy.

Although central Italy (and Latium in particular) is climatically (Blasi, 1994), geologically (Azzaro et al., 1976; Funicello et al., 1979; Varekamp, 1980) and topographically (Latium Region, 2013) well characterized, no studies were conducted on this area to confirm the idea that invertebrates diversity may be affected by both hydroecoregion and source distance. We used just these two latter descriptors to synthesize the former three features since our aim is to understand how the use of hydroecoregion and source distance may be used as discrimination criterion affecting the river monitoring activities, and not to understand which environmental features may affect the macroinvertebrate distribution.

Therefore, in this paper we assessed if the hydroecoregion and source distance criterions may be an suitable division criterion in Mediterranean river basins in central Italy.

In this study, hydroecoregion and source distance did not seem to be a suitable grouping criterion when they are analyzed separately, while they provided a more satisfactory result working jointly. 


\section{Table IV}

Taxa that contributed up to $80 \%$ of Bray-Curtis dissimilarity (similarity percentage analysis) between hydroecoregions. Marks: Cont = contribution; $\%$ cont = taxa $\%$ contribution; Cum.per = cumulative percentage; m.a. = mean abundance.

\begin{tabular}{|c|c|c|c|c|c|}
\hline Taxon & cont. & $\%$ cont. & cum.per. & m.a. & m.a. \\
\hline & $\mathrm{H} 13$ & $\mathrm{H} 14$ \\
\hline Baetis sp. & 16.910 & $19.1 \%$ & $19.1 \%$ & 719 & 15 \\
\hline Echinogammarus sp. & 10.950 & $12.3 \%$ & $31.4 \%$ & 508 & 25 \\
\hline Simulidae & 8.714 & $9.9 \%$ & $41.3 \%$ & 448 & 38 \\
\hline Chironomidae & 7.543 & $8.5 \%$ & $49.8 \%$ & 226 & 175 \\
\hline Serratella sp. & 5.608 & $6.3 \%$ & $56.1 \%$ & 266 & 50 \\
\hline Leuctra sp. & 4.536 & $5.1 \%$ & $61.2 \%$ & 226 & 7 \\
\hline Hydracarinae & 4.431 & $5 \%$ & $66.2 \%$ & 5 & 218 \\
\hline Haplotaxidae & 3.156 & $3.6 \%$ & $69.8 \%$ & 35 & 10 \\
\hline Elmintidae & 2.735 & $3.1 \%$ & $72.9 \%$ & 101 & 7 \\
\hline Limnephilus sp. & 2.414 & $2.7 \%$ & $75.6 \%$ & 51 & 9 \\
\hline Hydropsiche sp. & 1.945 & $2.2 \%$ & $77.8 \%$ & 29 & 16 \\
\hline Habrophlebia sp. & 1.595 & $1.8 \%$ & $79.6 \%$ & 43 & 4 \\
\hline Ephemera sp. & 1.231 & $1.4 \%$ & $81.0 \%$ & 30 & - \\
\hline & $\mathrm{H} 13$ & $\mathrm{H} 15$ \\
\hline Chironomidae & 14.890 & $18.2 \%$ & $18.2 \%$ & 226 & 874 \\
\hline Baetis sp. & 11.760 & $14.3 \%$ & $32.5 \%$ & 719 & 248 \\
\hline Echinogammarus sp. & 8.258 & $10.1 \%$ & $42.6 \%$ & 508 & 98 \\
\hline Serratella sp. & 6.650 & $8.1 \%$ & $50.7 \%$ & 266 & 210 \\
\hline Simulidae & 6.587 & $8 \%$ & $58.7 \%$ & 448 & 42 \\
\hline Bithynia sp. & 4.022 & $4.9 \%$ & $63.6 \%$ & 12 & 144 \\
\hline Leuctra sp. & 3.478 & $4.3 \%$ & $67.9 \%$ & 226 & 4 \\
\hline Hydropsiche sp. & 2.018 & $2.4 \%$ & $70.3 \%$ & 29 & 92 \\
\hline Elmintidae & 1.840 & $2.3 \%$ & $72.6 \%$ & 101 & 22 \\
\hline Haplotaxidae & 1.617 & $1.9 \%$ & $74.5 \%$ & 35 & 16 \\
\hline Limnephilus sp. & 1.399 & $1.7 \%$ & $76.2 \%$ & 51 & - \\
\hline Ephemera sp. & 1.221 & $1.5 \%$ & $77.7 \%$ & 30 & 24 \\
\hline Hydracarinae & 1.217 & $1.5 \%$ & $79.2 \%$ & 5 & 56 \\
\hline Lymnaea sp. & 1.142 & $1.4 \%$ & $80.6 \%$ & 12 & 50 \\
\hline & $\mathrm{H} 14$ & $\mathrm{H} 15$ \\
\hline Chironomidae & 22.270 & $25.9 \%$ & $25.9 \%$ & 175 & 874 \\
\hline Baetis sp. & 8.656 & $10.1 \%$ & $36.0 \%$ & 15 & 248 \\
\hline Bithynia sp. & 8.004 & $9.3 \%$ & $45.3 \%$ & - & 144 \\
\hline Serratella sp. & 7.906 & $9.2 \%$ & $54.5 \%$ & 50 & 210 \\
\hline Hydracarinae & 6.527 & $7.6 \%$ & $62.1 \%$ & 218 & 56 \\
\hline Echinogammarus sp. & 4.735 & $5.5 \%$ & $67.6 \%$ & 25 & 98 \\
\hline Hydropsiche sp. & 2.770 & $3.2 \%$ & $70.8 \%$ & 16 & 92 \\
\hline Simulidae & 2.204 & $2.6 \%$ & $73.4 \%$ & 38 & 42 \\
\hline Platycnemis sp. & 1.820 & $2.1 \%$ & $75.5 \%$ & 26 & 16 \\
\hline Lumbricidae & 1.783 & $2.1 \%$ & $77.6 \%$ & 20 & 26 \\
\hline Calopteryx sp. & 1.699 & $1.9 \%$ & $79.5 \%$ & 4 & 32 \\
\hline Caenis sp. & 1.679 & $2.0 \%$ & $81.5 \%$ & 7 & 36 \\
\hline
\end{tabular}

In particular, our outputs showed a weak site separation among hydroecoregions (beHER) and source distance ranks (beSD) by using physico-chemical variables. The same output was obtained among hydroecoregions (beHER) when we used data on macroinvertebrate. Anyway, the most evident result regard the differences among sites of different hydroecoregions within the same source distance rank (wiSD). This is probably due to differences in the abundances of each single taxon rather than in the number of taxa (Supplementary material I).

The importance of physico-chemical variables for determining macroinvertebrate assemblages was largely evaluated (Wright et al., 1984; Richards et al., 1993; Murphy and Davy-Bowker, 2005). All environmental variables showed better quality values in upstream sampling sites decreasing from upstream to downstream ones following the natural 


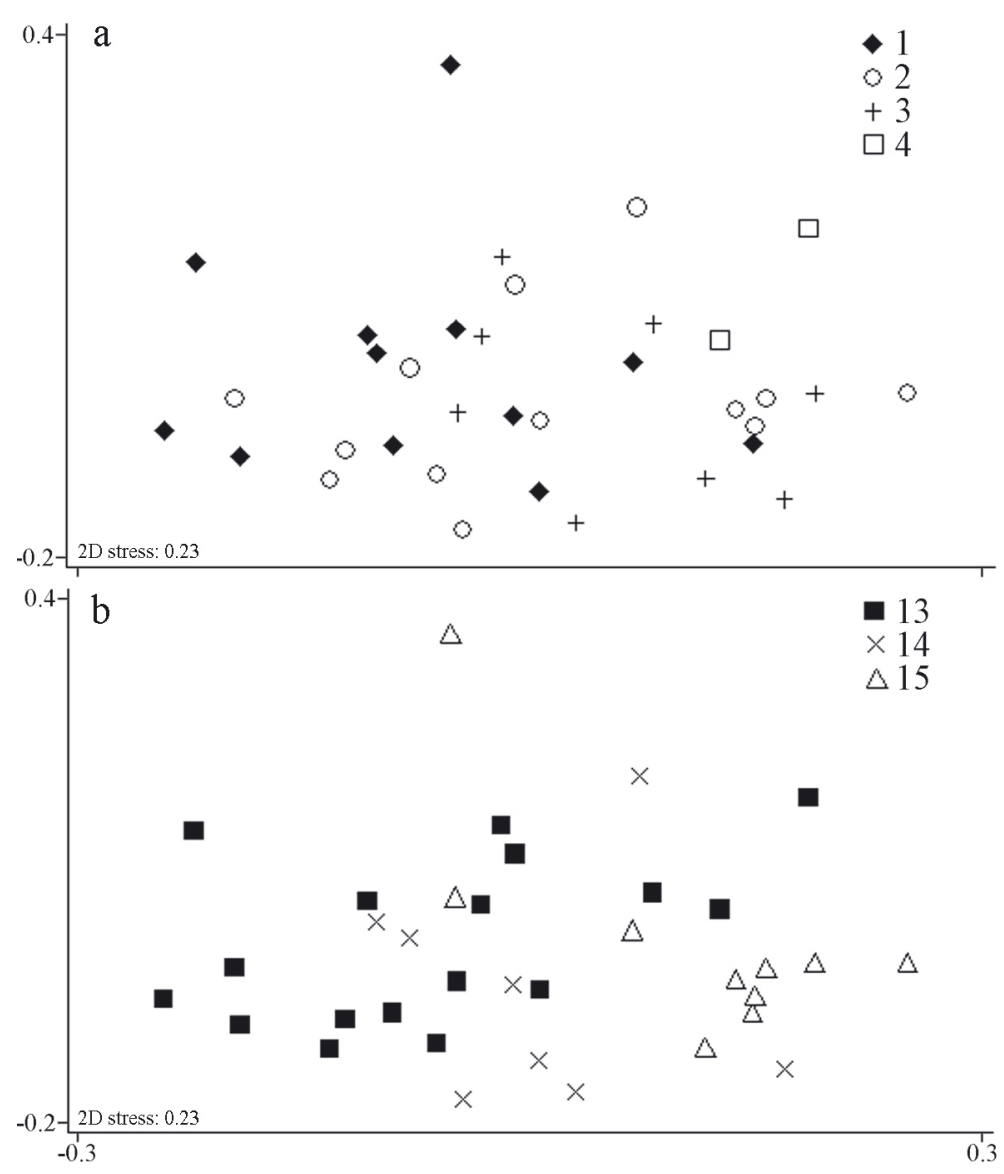

Figure 3

Non-metric multidimensional scaling ordinations. The site disposition is the same in both diagrams, depicted using source distance ranks (a) and hydroecoregions (b). Acronym number define the SD and the HER of each sampling site $(1=S D 1,2=S D 2,3=S D 3,4=S D 4,13=H E R 13,14=H E R 14,15=$ HER15).

upstream-downstream gradient (Schlosses, 1990). Great attention may be focus on the parameters used to define HER (Wasson et al., 2002). In particular, the remarkable geological diversity of investigated sampling sites play a key role influencing also river hydrological features and varying water chemical composition (Wasson et al., 2002). Geological diversity corresponds in soils characterized by different chemical compositions resulting in a different amount of chemicals able to modify water quality, such as calcium carbonate and magnesium (Khaledian et al., 2012; Prasath et al., 2013). Geological diversity has also an important influence on the sediment composition that may result in a physical alteration of the riverbed (von Bertrab et al., 2013). Previous studies showed the influence of sediment on macroinvertebrate assemblages (Allan, 1995; Subramanian and Sivaramakrishnan, 2005) including fine sediments (Angradi, 1999). In particular fine sediments strongly characterize the HER15. Indeed, this is an hydroecoregion characterized by fine sediments transported by rivers over thousands of years and it clearly distinguish this hydroecoregion from the other two (Boni et al., 1988). In addition, the greater number of industries and human activities in the HER15 territory than in the other two hydroecoregions highly contribute to mostly degrade water quality spilling sewage into rivers (Sappa et al., 2005). All these considerations were also confirmed by Spearman's correlations. Indeed, the three parameters correlated with the PC1 are a good proxy of water quality (Sánchez-Montoya et al., 2012). The greatest separation between HER for the three wiSD groups underlined the importance of using both levels of site classifications in evaluating physico-chemical differences between sites. 

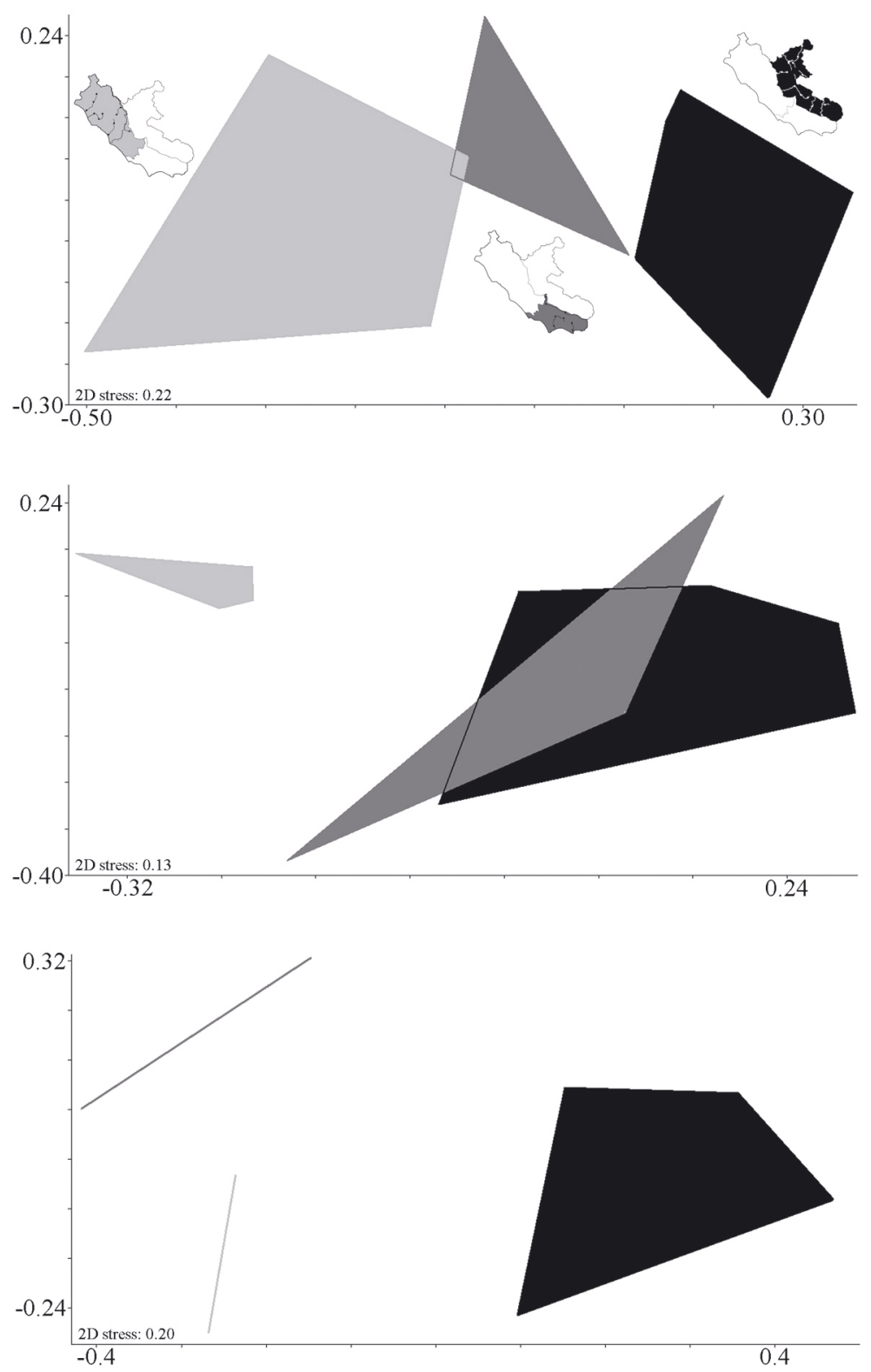

Figure 4

Non-metric multidimensional scaling ordinations where sites are divided per hydroecoregions within the same source distance $(S D 1=1-5 \mathrm{~km}$ distance rank from the source, above; $S D 2=6-25 \mathrm{~km}$, in the middle; SD3 = 26-75 km, below). SD4 (76-150 km) and SD5 (>150 km) were not considered since the lower number (2) or absence of sites, respectively.

Indices and metrics are generally used as a proxy of water quality and of structure of macroinvertebrate assemblages (AQEM consortium, 2002; Lewin et al., 2013; Manfrin et al., 2013). The LUI output confirms that HER15 sites showed the highest anthropic impact, the opposite for HER13, confirming the PCA scatter plot. IFF confirmed obtained outputs. A progressive deterioration of the river functionality index (IFF) from HER13 sampling sites and HER15 ones was highlighted. A decrease of index value is a function of an increase in the alteration of the river functionality generally associated with an increased impact mainly due to human activities (Siligardi et al., 2007; Comiti et al., 2009).

The lower number of t-test significances for wiSD than for beHER and beSD were probably related to the reduced number of sampling sites and to the more uniformity in rivers features and macroinvertebrate assemblage compositions observed within SD. Notwithstanding, the 
highest significant difference observed between HER13 and HER14 in SD2 and SD3 clearly support and reinforce that obtained from HER sites, indicating a deeply consistent difference between HER13 sites vs. HER14 ones based on metrics. These outputs confirmed the usefulness of t-test to evaluate differences between metrics, as shown by Aboua et al. (2012). The importance of using metrics as sites descriptors was further confirmed by Spearman's correlation between physico-chemicals PCs vs. metrics since almost all metrics (excepted for evenness) were significantly correlated with PC1. This axes was a useful descriptor of heterogeneity between hydroecoregions as argued above.

Differences in macroinvertebrate assemblages were highlighted by ANOSIM and NMDS analysis. ANOSIM major differences were found comparing wiSD while not distinctive assemblages were founded for beHER. In particular, this analysis showed a significant similarity for beHER (mainly between HER13 vs. HER14 and between HER14 vs. HER15) while significant differences were obtained for wiSD with few exception (probably occasional and random). NMDS scatter plots confirmed ANOSIM result since not distinctive assemblages were obtained for beSD and beHER. Indeed, noticeable distinctive assemblages were obtained for wiSD. These findings are in contrast with ones obtained by Urbanič (2008) and by Tavzes and Urbanič (2009) which did not obtain significant differences in macroinvertebrate assemblages between Alpine hydroecoregions using NMDS whith macroinvertebrate abundances. On the contrary, Wasson et al. (2002) better explained how one of the most important parameters in differentiating hydroecoregions are the macroinvertebrate assemblages. Our SIMPER findings demonstrated that greater densities of benthic macroinvertebrates in different hydroecoregions were effectively reflected by differences in species composition mainly related to taxa mean abundances than to the few dominant taxa per HER.

Our findings did not allow to describe differences between sampling sites when sites were grouped only for hydroecoregion or source distance separately, for both environmental variables and macroinvertebrate communities. Instead, a more precise evaluation of the same differences may be obtained considering these HER and SD together. It was confirmed by the strongest separation obtained between HERs when the wiSD groups were considered. Our findings also showed how a sampling sites classification taking into account both HER and SD information is better to evaluate real differences between sampling sites and can actually allow to better assess differences between the investigated sampling sites.

The synergy between hydroecoregions and source distance allow to obtain a suitable river grouping, indicating that they should be used as an available monitoring tool for the environmental assessment in Mediterranean catchments.

We argue that monitoring programs should consider a multi-assemblage assessment, as also required by the Water Framework Directive. In fact, our findings support the requirements of the European Water Framework Directive in the need of simultaneous river classification by using two main criterions to propose an available tool for the ecological status assessment of aquatic ecosystems.

\section{ACKNOWLEDGEMENTS}

We are indebted to Dr. Giorgio Pace, for his help during data analysis. In particular, we thank him for his advices and for his expert judgments.

\section{REFERENCES}

Aboua B.R.D., Kouamelan E.P. and N'Douba V., 2012. Development of a fish-based index of biotic integrity (FIBI) to assess the quality of Bandama River in Cote d'Ivoire. Knowl. Managt. Aquatic. Ecosyst., 404, 08, 19 p.

Aguiar F.C., Ferreira M.T. and Pinto P., 2002. Relative influence of environmental variables on macroinvertebrate assemblages from an Iberian basin. J. N. Am. Benthol. Soc., 21, 43-53. 
Allan D.J., 1995. In Stream Ecology: Structure and Function of Running Waters, Chapman \& Hall, Chennai, $388 \mathrm{p}$.

Almeida D., Merino-Aguirre R. and Angeler D.G., 2013. Benthic invertebrate communities in regulated Mediterranean streams and least-impacted tributaries. Limnologica, 43, 34-42.

Álvarez-Cabria M., Barquín J. and Juanes J.A., 2011. Macroinvertebrate community dynamics in a temperate European Atlantic river. Do they conform to general ecological theory? Hydrobiologia, 658, 277-291.

Angradi T.R., 1999. Fine sediment and macroinvertebrate assemblages in Appalachian streams: a field experiment with biomonitoring applications. J. N. Am. Benthol. Soc., 18, 49-66.

AQEM consortium, 2002. Manual for the application of the AQEM method. A comprehensive method to assess European streams using macroinvertebrates, developed for the purpose of the Water Framework Directive. Version 05/2002.

Azzaro E., Cocozza T., Di Sabatino B., Gasperi G., Gelmini R. and Lazzarotto A., 1976. Geology and Petrography of the Verrucano and Paleozoic Formations of Southern Tuscany and Northern Latium (Italy). The Continental Permain in Central, West, and South Europe. Nato Advanced Study Institutes Series, 22, 181-195.

Blasi C., 1994. Fitoclimatologia del Lazio. Fitosociologia, 27, 151-175.

Boni C., Bono P. and Capelli G., 1988. The hydrogeological map for the Latium Region territory. 1:250.000 scale. Special pubblication of the Latium Region, Italy.

Buffagni A., Munafò M., Tornatore F., Bonamini I., Didomenicantonio A., Mancini L., Martinelli A., Scanu G. and Sollazzo C., 2006. Elementi di base per la definizione di una tipologia per i fiumi italiani in applicazione della direttiva 2000/60/EC. IRSA - CNR.

Clarke K.R., 1993. Non-parametric multivariate analyses of changes in community structure. Aust. J. Ecol., 18, 117-143.

Comiti F., Mao L., Lenzi M.A. and Siligardi M., 2009. Artificial steps to stabilize mountain rivers: a postproject ecological assessment. River Res. Appl., 25, 639-659.

Feeley H.B., Woods M., Baars J. and Kelly-Quinn M., 2012. Refining a kick sampling strategy for the bioassessment of benthic macroinvertebrates in headwater streams. Hydrobiologia, 683, 53-68.

Feio M.J., Coimbra C.N. and Graca M.A.S., 2010. The influence of extreme climatic events and human disturbance on macroinvertebrate community patterns of a Mediterranean stream over $15 \mathrm{y} . \mathrm{J} . \mathrm{N}$. Am. Benthol. Soc., 29, 1397-1409.

Frissell C.A. and Bayles D., 1996. Ecosystem management and the conservation of acquatic biodiversity and ecological integrity. Water Resour. Bull., 32, 229-240.

Funicello R., Mariotti G., Parotto M., Preite-Martinez M., Tecce F., Toneatti R. and Turi B., 1979. Geology, mineralogy and stable isotope geochemistry of the cesano geothermal field (Sabatini Mis. Volcanic system, Northern Latium, Italy). Geothermics, 8, 55-73.

Hering D., Moog O., Sandin L. and Verdonschot P.F.M., 2004. Overview and application of the AQEM assessment system. Hydrobiologia, 516, 1-20.

Holm S., 1979. A simple sequentially rejective multiple test procedure. Scand. J. Stat., 6, 65-70.

Illies J., 1978. Limnofauna Europaea. A checklist of the Animals inhabiting European Inland Waters, with Account of their Distribution and Ecology. G. Fischer, Stuttgart and Swets \& Zeitlinger, Amsterdam, $532 \mathrm{p}$.

Khaledian Y., Kiani F. and Ebrahimi S., 2012. The effect of land use change on soil and water quality in northern Iran. J. Mt. Sci., 9, 798-816.

Kruskal J.B., 1964a. Multidimensional scaling by optimizing goodness of fit to a nonmetric hypothesis. Psychometrika, 29, 1-27.

Kruskal J.B., 1964b. Nonmetric multidimensional scaling: a numerical method. Psychometrika, 29, 115-129.

Latium Region, 2013. Available from: http://www.regione.lazio.it/rl_ambiente/?vw=contenutiDettaglio\& $\mathrm{id}=67$.

Lewin I., Czerniawska-Kusza I., Szoszkiewicz K., Ławniczak A.E. and Jusik S., 2013. Biological indices applied to benthic macroinvertebrates at reference conditions of mountain streams in two ecoregions (Poland, the Slovak Republic). Hydrobiologia, 709, 183-200. 
Manfrin A., Larsen S., Traversetti L., Pace G. and Scalici M. 2013. Longitudinal variation of macroinvertebrate communities in a Mediterranean river subjected to multiple anthropogenic stressors. Int. Rev. Hydrobiol., 98, 155-164.

Murphy J.F. and Davy-Bowker J., 2005. Spatial structure in lotic macroinvertebrate communities in England and Wales: relationship with physical, chemical and anthropogenic stress variables. Hydrobiologia, 534, 151-164.

Ometo J.P.H.B., Martinelli L.A., Ballester M.V., Gessner A., Krusche A.V., Reynaldo L., Victorla R.L. and Cena M.W., 2000. Effects of land use on water chemistry and macroinvertebrates in two streams of the Piracicaba river basin, south-east Brazil. Freshwater Biol., 44, 327-337.

Pace G., Andreani P., Barile M., Buffagni A., Erba S., Mancini L. and Belfiore C., 2011. Macroinvertebrate assemblages at mesohabitat scale in small sized volcanic siliceous streams of Central Italy (Mediterranean Ecoregion). Ecol. Indic., 11, 688-696.

Pace G., Della Bella V., Barile M., Andreani P., Mancini L. and Belfiore C., 2012. A comparison of macroinvertebrate and diatom responses to anthropogenic stress in small sized volcanic siliceous streams of Central Italy (Mediterranean Ecoregion). Ecol. Indic., 23, 544-554.

Petersen R.C., 1992. The RCE: a Riparian, Channel, and Environmental Inventory for small streams in the agricultural landscape. Freshwater Biol., 27, 295-306.

Prasath B.B., Nandakumar R., Kumar S.D., Ananth S., Deva A.S., Jayalakshmi T., Raju P., Thiyagarajan M. and Santhanam P., 2013. Seasonal variations in physico-chemical characteristics of pond and ground water of Tiruchirapalli, India. J. Environ. Biol., 34, 529-537.

Reyjol Y., Beier U., Bianco P.G., Caiola N., Casals F., Cowx I., De Sostoa A., Economou A., Ferreira T., Haidvog G., Hugueny B., Noble R., Pont D., Vigneron T. and Virbickas T., 2007. Patterns in species richness and endemism of European freshwater fish. Global Ecol. Biogeogr., 16, 65-75.

Ricciardi A. and Rasmussen J.B., 1999. Extinction rates of North American freshwater fauna. Conserv. Biol., 13, 1220-1222.

Richards C., Host G.E. and Arthur J.W., 1993. Identification of predominant environmental factors structuring stream macroinvertebrate communities within a large agricultural catchment. Freshwater Biol., 29, 285-294.

Sánchez-Montoya M.M., Arce M.M., Vidal-Abarca M.R., Suárez M.L., Prat N. and Gómez R., 2012. Establishing physico-chemical reference conditions in Mediterranean streams according to the European Water Framework Directive. Water Res., 46, 2257-2269.

Sappa G., Rossi M. and Coviello M.T., 2005. Effetti ambientali del sovrasfruttamento degli acquiferi della Pianura Pontina (Lazio). Aquifer Vulnerability and Risk, 2nd International Workshop.

Schlosser I.J., 1990. Environmental variation, life history attributes, and community structure in stream fishes: Implications for environmental management and assessment. Environ. Manage., 14, 621-628.

Schlosser I.J., 1991. Stream Fish Ecology: A Landscape Perspective. Bioscience, 41, 704-712.

Siligardi M., Bernabei S., Cappelletti C., Chierici E., Ciutti F., Egaddi F., Franceschini A., Maiolini B., Mancini L., Minciardi M.R., Monauni C., Rossi G., Sansoni G., Spaggiari R. and Zanetti M., 2007. I.F.F. 2007. Indice di Funzionalità Fluviale. Manuale APAT/2007.

Smith K.G. and Darwall W.R.T., 2006. The status and distribution of freshwater fish endemic to the Mediterranean Basin. IUCN, Gland, Switzerland and Cambridge, UK.

Subramanian K.A. and Sivaramakrishnan K.G., 2005. Habitat and microhabitat distribution of stream insect communities of the Western Ghats. Curr. Sci., 89, 976-987.

Tachet H., Richoux P., Bournaud M. and Usseglio-polatera P., 2000. Invertebres d'eau Douce. Systematique, Biologie, Ecologie. CNRS Editions, Paris, 587 p.

Tavzes B. and Urbanič G., 2009. New indices for assessment of hydromorphological alteration of rivers and their evaluation with benthic invertebrate communities; Alpine case study. Rev. Hydrobiol., 2, 133-161.

Tomanova S., Tedesco P.A., Campero M., Van Damme P.A., Moya N. and Oberdorff T., 2007. Longitudinal and altitudinal changes of macroinvertebrate functional feeding groups in neotropical streams: a test of the River Continuum Concept. Fund. Appl. Limnol., 170, 233-241.

Traversetti L., Manfrin A. and Scalici M., 2013. Remapping hydroecoregion boundaries: a proposal for improving the base of the running water monitoring procedures. J. Basic Appl. Sci., 9, 533-537. 
Turak E., Flack L.K., Norris R.H., Simpson J. and Waddell N., 1999. Assessment of river condition at a large spatial scale using predictive models. Freshwater Biol., 41, 283-298.

Urbanič G., 2008. Inland water subecoregions and bioregions of Slovenia. Natura Sloveniae, 10, 5-19.

Vannote R.L., Minshall G.W., Cummins K.W., Sedell J.R. and Cushing C.E. 1980. The River Continuum Concept. Can. J. Fish. Aquat. Sci., 37, 130-137.

Varekamp J.C., 1980. Geology and petrology of the Vulsinian volcanic area (Latium, Italy). Geol. Ultraiect., 22, 1-384.

Von Bertrab M.G., Krein A., Stendera S., Thielen F. and Hering D., 2013. Is fine sediment deposition a main driver for the composition of benthic macroinvertebrate assemblages? Ecol. Indic., 24, 589-598.

Wasson J.G., Blanc L., Chandesris A. and Pella H., 2002. Définition des hydro-écoregions de France métroplolitaine. Approche regionale de typologie des eaux courantes et éléments pour la définition des peuplements de référence d'invertébrés. Cemagref, Lyon BEA/LHQ.

Wright J.F., Moss D., Armitage P.D. and Furse M.T. 1984. A preliminary classification of running water sites in Great Britain based on macro-invertebrate species and prediction of community type using environmental data. Freshwater Biol., 14, 221-256. 